\title{
DE OPLEIDING TOT ACCOUNTANT IN DE U.S.A.
}

door Drs L. F. Jansen

Het is niet zo eenvoudig om in kort bestek een overzicht te geven van de opleiding tot accountant in de Verenigde Staten zonder daarbij verwarring te stichten. De oorzaak hiervan moet gezocht worden in het feit, dat Amerika 48 Staten telt welke ieder eigen regels hebben om Certified Public Accountant, dus C. P. A. te worden. Ook Washington D.C., de zetel van de Federale Regering heeft weer eigen regels.

Ik zeg ",regels", omdat het C.P.A. examen in de meeste staten uniform is. Duidelijker uitgedrukt: men neemt hetzelfde uniforme C.P.A. examen af in bedoelde diverse staten, doch de eisen van toelating tot dat examen in de diverse staten verschillen.

Niet alleen dat, maar bovendien is de terminologie der benaming van de scholen, die men met goed gevolg moet doorlopen hebben, vaak ook nog verschillend. Vrijwel algemeen moet men in de eerste plaats de „High School"' achter de rug hebben, wat onder normale omstandigheden op 18-jarige leeftijd wel het geval is. De "High School" is dus het Amerikaanse equivalent voor de Nederlandse H.B.S. De eisen voor het eindexamen zijn echter niet zo zwaar, omdat men niet gedwongen is enige talen te leren, noch ook veel met wiskunde of natuurkunde wordt lastig gevallen. Men heeft meestal het systeem van keuze-vakken en de High School scholier kan het zich gemakkelijk, minder gemakkelijk of moeilijker maken. Resultaat is b.v. een groot tekort h.t.l. aan mathematici, physici, ingenieurs en medici.

Aan een recent artikel (Editorial) in de New York Times, getiteld: "An Alarming Situation" is het volgende ontleend:

,A sense of shock must be felt by any thinking citizen who studies the state of science teaching in our high schools as described in these columns yesterday. Only about half of our high schools offer courses in chemistry or physics, and less than 5 percent of our high school students study even elementary algebra, and little more than ten percent take geometry. Hundreds of thousands of youngsters who do study science or mathematics inour high schools do so under unqualified teachers. For every 3 science teachers needed by our schools this fall, there will be only one qualified person available."

en voorts:

.We need scientists, mathematicians and engineers as never before, yet many teen-agers with the ability to assume such roles are simply not being given a chance to get the essential training.

The statistics make plain that great mistakes have been made in thousands of communities throughout our land. School administrators acting out of ignorance themselves or bowing to pressure from those who would spare youngsters the rigors of real intellectual adventure, have let the teaching of science and mathematics decline and disappear. To reverse this tide will not be easy, yet reversed it must be if our nation is to remain strong and healthy."

Het diploma High School geeft niet, zoals in Nederland, automatisch recht om zich aan een instelling van hoger onderwijs te laten inschrijven, 
zelfs al zegt het verworven High School diploma, dat een ,academical course" werd gevolgd. Meestal betekent dit, dat de gemiddeld behaalde cijfers "hoog" waren. Zijn de cijfers niet hoog, dan wordt b.v. een diploma uitgereikt - nog steeds een High School diploma, - dat ver meldt, dat een ,,general course" werd gevolgd, of, als men enkele handelsvakken heeft gevolgd en behoorlijke cijfers heeft behaald, een ,,business course".

Vervolgens meldt de student ,in spé" zich aan voor een z.g. „College" - meestal een 4 jarige cursus. Dit gaat niet steeds zo eenvoudig. want men moet veelal ......... toelatingsexamen doen. Op basis hiervan en op basis van de cijfers van de High School wordt over toelating tot het "College" beslist. Het High School diploma geeft niet ,ipso facto" recht op toelating tot een "College" en het niet bezitten van een High School diploma is niet steeds een bezwaar om toch tot een College te worden toegelaten.

Men denke er aan dat sommige Colleges zich High School noemen, en sommige High Schools noemen zich College.

Wat is het doel van de 4-jarige opleiding tot een College degrees? De doelstellingen zijn zeer verschillend. Men eindigt met een soort academische graad van lagere orde: B.A., wat betekent Bachelor of Arts, of B.S., wat Bachelor of Science betekent. Intussen, diploma's van een zelfde College kunnen wederom op zichzelf verschillende waarden hebben; dan zijn er Colleges met verschillende standaarden, keuzevakken, enz.

Voor sommige richtingen heeft een College degree de betekenis van de succesvolle beëindiging van de studie. Voor andere richtingen echter doet het herinneren aan ons candidaats-examen. Met een College degree B.S. kan men b.v. worden toegelaten tot de "School of Medicine", waar men tot arts opgeleid wordt. Met ofwel een B.A. of een B.S. degrees, ( - studenten die voor Law opgeleid worden, en een wiskundige achtergrond hebben, geven, zoals bewezen is, de beste resultaten! -) kan men toegelaten worden tot de "School of Law" ( 3 jaar), wil men jurist worden. Deze laatste "schools" komen dus ongeveer overeen met de universiteiten in Nederland na de resp. candidaatsexamens, dus leidende tot de doctoraal examens Rechten of Medicijnen.

Wil men dan nog geen afscheid nemen van het universitaire onderwijs dan kan men nog ",specialiseren" en een of andere "Master degree" (M.A. of M.S.) behalen, of b.v. promoveren, waarmede als regel een of twee jaren gemoeid zijn.

Andere studierichtingen echter worden afgesloten met een college degree, dus - als regel - vier jaren, nadat men de deuren van de High School achter zich gesloten heeft, of wel na vijf of zes jaren, als men een avondcursus heeft gevolgd.

Tot deze richtingen behoren de studies voor ingenieurs, accountants, leraren, onderwijzers, verpleegsters, en andere.

Laten we ons nu verder bepalen tot de studie voor Certified Public Accountant (C.P.A.).

In de eerste plaats moet het juiste College worden gekozen. In New York City heeft men de keuze tussen, b.v.:

\section{College of the City of New York}

Bernard M. Baruch School of Business and Public Administration. ( 4 of 5 jaren) 
Columbia University

School of Business (4-5 of 6 jaren)

Institute of accounting

Fordham University

School of Business ( 4 jaren dag-cursus of 5 of 6 jaren avond-cursus)

New York University

Graduate School of Business Administration, or School of Commerce.

\section{St. John's University}

School of Accounting, Commerce and Finance.

Behalve aan deze kan men aan nog minstens 120 andere over geheel Amerika verspreide Universitaire Instellingen een College Degree verwerven, welke geaccrediteerd is in New York State.

Het is zeer wel mogelijk, dat andere staten een nog langere lijst van geaccrediteerde instellingen kennen. New York State is n.l. nogal zwaar op de hand, niet alleen voor wat accountants betreft.

$\mathrm{Nu}$ denke men niet, dat men een Certified Public Accountant (C.P.A.) wordt, alleen maar door het behalen van een College degree. Althans voor wat New York betreft, bestaat de eis, dat men bovendien nog op drie jaren practijk kan wijzen:

"Who have completed three year's experience in the intensive diversified application of accounting principles and in the intensive diversified application of auditing procedures, in the public practice of accountancy satisfactory to the State Board of C.P.A. examiners, subject to review by the Commissioner of Education.

( To be completed not less than 90 days prior to the date of examination.)

Men neme dit niet al te ernstig. Een jonge man van plus minus 25 jaar met 3 jaar practijk achter de rug en dan geschoold in de ,intensive diversified application of accounting principles and auditing principles" klinkt wel wat onwaarschijnlijk. Deze hap is wat te groot om helemaal naar de letter te mogen worden genomen.

Men lette er op, dat de a.s. C.P.A. drie jaren practijk moet hebben, doch niét drie jaren practijk op het kantoor van een C.P.A.; dat mag ook zijn op het kantoor van een Public Accountant (P.A.). En het mag ook $z$ ijn ...... een eigen practijk. M.a.w. de accountancy is een zodanig beroep in New York State - niet in alle Staten - dat het onbevoegd uitoefenen van de accountancy niet bestaat. Integendeel ........ het wordt of ficieel erkend.

Gewapend nu met de hierboven in het kort besproken College degree plus drie jaren goedgekeurde praktijk, plus enkele andere ,requirements" van ondergeschikt belang, kan de candidaat worden toegelaten tot het laatste examen, het C.P.A. examen van de State of New York:

Article XI 91 of the Regulations of the Commissioner, zegt onder meer:

\section{PROFESSIONAL REQUIREMENTS.}

The examination in certified public accountancy shall consist of: Group 1: 
The subjects of theory of accounts and of commercial law. (dit bevat tevens belastingrecht)

Group 2:

The subjects of practical accounting and of auditing, etc. etc.

Men mag zich voor groep 1 en groep 2 terzelfder tijd aanmelden; men dient echter geslaagd te zijn voor groep 1 wil men kunnen slagen voor groep 2. Als de candidaat voor beide onderdelen geslaagd is, verwerft hij daardoor de officieel - beschermde - titel van Certified Public Accountant.

Ofschoon de vooropleiding, die verlangd wordt alvorens men tot de accountantsstudie (College) kan worden toegelaten, veel bescheidener is, n.l. High School, dan b.v. voor de rechtsstudie, waarvoor een College degree - als regel - als basis wordt verlangd, mag hieruit niet de conclusie getrokken worden, dat het C.P.A. examen uitgesproken lichter is dan het eindexamen voor rechten: de z.g. "Bar Examination”. Personen. die beide examens hebben gedaan, schijnen die mening toegedaan te zijn. Uit de aard der zaak is het uiterst moeilijk een objectieve maatstaf voor de graad van zwaarte van verschillende examens te vinden. Aanleg speelt een grote rol in beide bedoelde richtingen.

Een zeer groot aantal personen en firma's, die in de Staat New York de accountancy beoefenen zijn geen C.P.A.'s. Nog onlangs deelde een deskundige mij mede, dat van de vijf en twintig partners van een firma met een reputatie, welke zich buiten de grenzen van het land uitstrekt, geen enkele een C.P.A. zou zijn.

Reeds eerder heb ik de opmerking gemaakt, dat de State of New York nog al zwaar op de hand is, en betrekkelijk hoge eisen stelt. Dit is niet overal het geval. Hieronder volgen, om een voorbeeld te geven, de eisen, welke de hoofdstad: Washington D.C. (District of Columbia), stelt:

a. High School, or equivalent, or, who in the opinion of the Board has sufficient commercial experience in accounting.

AND

b. 1) who has received a diploma from some recognized school of accounting AND has had one year's experience in the employment of a practicing certified public accountant.

OR

2) has three year's experience in the employment of a practicing certified public accountant.

In lieu of the experience in the employ of a practicing C.P.A. an applicant may have not less than 5 years actual and continious experience in auditing the books and accounts of other persons in three or more distinct lines of commerce business. This applies only to experience acquired as an independent public accountant 1 ).

De enige mij bekende Universiteit, die met schriftelijke cursussen werkt: La Salle Extension University, Chicago, Ill., geeft na afloop van de cursus een diploma ,, higher accountancy", welk diploma aanspraak

1) dus: eigen praktijk als public accountant.

$\mathrm{ma} \mathrm{b}$ blz. 502 
geeft op de korting van twee jaren, zodat slechts éen jaar ervaring vereist is onder een praktiserend certified public accountant. Dit diploma „Higher Accountancy" kan men verwerven binnen een tijdvak van vier jaren, omdat men niet gebonden is aan de periode waarin een mondelinge cursus gegeven wordt. Er schijnen gevallen te zijn geweest van personen die in twee jaren gereed kwamen.

Slaagt men nu voor het C.P.A. examen in Washington, D.C., dan heeft men aldaar de titel Certified Public Accountant. Deze titel mag men overal voeren, mits men maar duidelijk doet uitkomen: ,in Washington, D.C." Het wordt dus, b.v.: ..John D. Peterson - C.P.A.-Wash., D.C." Als Peterson zich nu in New York State wil vestigen en praktiseren, dan is daar niets op te zeggen. Hij mag zijn titel op bovenbedoelde wijze voeren, ook al is hij dan naar de officiële opvattingen van de wetgevers en autoriteiten geen New York State C.P.A. Dit is geen bezwaar, want, zoals in een beslissing van een rechtbank in New York wordt opgemerkt:

.,The legislative intent is perfectly plain. There is nothing in the statute to prohibit one from following the vocation of an accountant.

The statute is designed to prevent an accountant from holding himself out as a CERTIFIED public accountant untill he shall have obtained a certificate from the Regents of the University."

(d.w.z. de Staat New York, niet alleen het College).

Met andere woorden, Peterson is in New York State een ,public accountant", niet een certified public accountant. Het spreekt echter wel vanzelf dat zijn handtekening bij de Federale fiscale autoriteiten geaccrediteerd is. Ook bij de autoriteiten belast met de uitvoering van de Federal Securities Law: Security and Exchange Control. De Securities Exchange Act heeft soortgelijke bepalingen.

Met de titel ,.C.P.A. Wash., D.C." is men dus $95 \%$ onder dak, namelijk ook in alle staten, die niet beslist een wetgeving hebben uitgevaardigd waarbij de public accountant (P.A.) zonder de vereiste titel verboden wordt als zodanig werkzaam te zijn. In de meeste staten is er echter geen bepaling, als hierbedoeld, opgelegd. Wel heeft men in 22 Staten een dubbel systeem ingevoerd, n.l. naast de klasse van C.P.A.'s nog een tweede klasse, n.l. die van Registered or Licensed Public Acm countant. In die staten is het verboden de public accountancy uit te oefenen zonder die vereiste qualificaties te bezitten.

(In New York State is dit echter niet het geval).

Tenslotte nog iets over de leerstof van de Colleges, die graden verlenen, welke toelating tot het C.P.A. examen beogen.

De eerder genoemde La Salle Extension University, - een "Correspondence Institution" in Chicago, geeft een ",training", bestaande uit 129 ,basic assignments", en 107 assignments in ,,certified public accounting training". Zoals het prospectus luidt:

„By devoting from four to five hours a week to the work, the average member will experience no difficulty in completing the assignments as they are received."

$\mathrm{Nu}$ zijn 129 plus 107 assignments in totaal 236 assignments. Als men iedere week 4 à 5 uren werkt is men er in 236 weken doorheen. Werkt 
men dus 8 a 10 uren per week, dan is men er in 118 weken doorheen, of in ruim twee jaren. Het kan dus ook korter.

De leerstof blijkt uit het volgend overzicht:
Practical Accounting
Accounting Principles
Accounting \& Statistical Control
Business Law
Corporate Organization and Management
Cost Accounting Procedure
Auditing Procedure
Accounting Systems
Design and Installation
Federal Income Tax Procedure
Certified Public Accountant Training

De prospectus van deze Universiteit zegt:

,The La Salle Higher Accountancy and C.P.A. training prepares for the uniform certified public accountant examination prepared by the American Institute of Accountants.

(De Staat stelt dus niet zijn eigen opgaven vast).

T'er illustratie volgt hieronder het programma van de vakken die de studenten aan de ,New York University School of Commerce, Accounts and Finance" moeten volgen om als a.s. C.P.A. het B.A. degree te verkrijgen.

\section{DE NEW YORK UNIVERSITY SCHOOL OF COMMERCE, ACCOUNTS, AND FINANCE}

geeft onder meer een vierjarige dagcursus, als volgt:

\begin{tabular}{|c|c|c|c|c|}
\hline Subjects & $\begin{array}{l}\text { Eerste jaar } \\
\text { uren p.w. }\end{array}$ & $\begin{array}{c}\text { Tweede jaar } \\
\text { uren p. w. }\end{array}$ & $\begin{array}{l}\text { Derde jaar } \\
\text { uren p. w. }\end{array}$ & $\begin{array}{l}\text { Vierde jaar } \\
\text { uren p. w. }\end{array}$ \\
\hline ACCOUNTING & 2 & 6 & 6 & 4 \\
\hline Banking $\&$ Finance & 2 & & & 2 \\
\hline Business English & 2 & & & 2 \\
\hline Economics & 2 & 2 & 2 & \\
\hline English & 2 & 2 & 2 & \\
\hline History of Civilisation & 2 & & & \\
\hline Management & 2 & & & \\
\hline Marketing & 2 & & & \\
\hline Law & & 2 & 2 & 2 \\
\hline Electives & & & & \\
\hline (non-professional) & & 4 & 4 & 4 \\
\hline Electives & & & & \\
\hline (professional) & & & & 2 \\
\hline Totaal & 16 & 16 & 16 & 16 \\
\hline
\end{tabular}

geeft het volgende:

ACCOUNTING (Eerste jaar)

Elementary Accounting.

The fundamental principles of accounting are studied and applied to

$\mathrm{m} \mathrm{a} \mathrm{b}$ blz. 504 
proprietorships, partnerships, and corporations. Topics include the bookkeeping process, adjusting entries, the construction and use of work sheets, and the preparation and basic use of financial statements; basic partnership problems (formation, allocation of profits, liquidation); and basic corporation accounting.

\section{ACCOUNTING (Tweede jaar).}

\section{Intermediate Accounting 1 .}

The first half deals with the fundamentals of manufacturing accounting (under both periodic and perpetual inventory), elementary problems of depreciation, depletion, and valuation; and an introduction to the responsibilities, interpretation, and use of financial statements.

The second half deals with accounting principles relating especially to problems of valuation for cash, accounts receivable, inventories, and installment sales. The effect of varying policies of valuation upon income is stressed.

\section{Intermediate Accounting II.}

Problems of valuation accounting and their effect upon income are studied, especially consignments, investments in securities, fixed and intangible assets, current and longterm liabilities. An examination of the nature of income and net worth is also made, followed by a thorough study of the organization, analysis, interpretation, and use of financial statements, inclusive of the statement of source and application of funds. The importance of matching costs and revenues is stressed.

\section{Business Mathematics.}

The first half covers the ordinary problems of business arithmetic, such as aliquot parts, practical short methods of calculation, fractions. percentages, interest and discount, and equation of accounts. The second half includes progressions, compound interest, annuities, sinking funds, amortization, depreciation, use of logarithms, etc.

\section{ACCOUNTING (Derde jaar).}

\section{Advanced Accounting.}

Principles and problems of advanced accounting relating to partnerships (including liquidation by installments), joint ventures, home-office and branch accounting, consolidated financial statements, corporate mergers and capital readjustments, foreign exchange, receiverships, and elementary fiduciary accounting.

\section{Cost Accounting.}

An elementary survey of the principles of cost accounting. After inquiry into the reasons for ascertaining costs, the course discusses various methods of accounting for materials, labor, and overhead consumed in job and process costing; and the assembly, presentation, and use of cost data. Selected cost systems in specific businesses are also studied.

\section{Federal Income Taxes.}

Analyzes the Federal Income Tax Law and its application to individuals, partnerships, fiduciaries, and corporations. Practical problems are used to illustrate the application of the law relating to the above classes of taxpayers. Particular attention is given to the preparation of incometax returns and other forms. 


\section{ACCOUNTING (Vierde jaar).}

Accounting problems.

Essentially a professional problems course using materials largely taken from past C.P.A. examinations of the American Institute of Accountants. During the second term, demonstration problems are worked in class under conditions simular to those of the C.P.A. examination.

\section{Auditing.}

During the first term the course develops along the following lines: auditing objectives and responsibilities, how to begin an audit, what to do during an audit, how to end an audit, what to do after an audit. During the second term the principles of auditing are applied through the medium of laboratory work, including the preparation of an audit report.

De Columbia University begint in September a.s. een opleiding van accountants in het nieuwe "Institute of Accounting", ,, another step in a steady and continuous growth in accounting education".

De cursus is vierjarig; gedurende het Universiteitsjaar, lopende van einde September tot het einde Mei wordt wekelijks 16 a 17 uren college gegeven. In die vier jaren moet de candidaat 130 punten verwerven om de betreffende B.S. degree te behalen. Hier onder volgt - ter afwisseling - een overzicht van de te behalen punten instede van het hierboven eerder gegeven jaarlijkse studie overzicht van de New York University:

\section{„THE INSTITUTE OF ACCOUNTING AT COLUMBIA UNIVERSITY".}

Course Requirements for the Institute Four Year Program.

1. Required Liberal Arts Courses

points total

68 points as follows:
a. English
b. History, Philosophy, Social Science
12
c. Mathematics or Physics or Natural Science
12
d. Introductory Economics
e. Fine Arts
Music 1
Fine Arts 1
f. Foreign Languages
g. Liberal Arts Electives

2. Required Technical Courses

Total Liberal Arts

62 points as follows:

a. Business Institutions

b. Accounting

c. Business Law

d. Finance (incl. Taxes)

e. Economics (incl. Statistics)

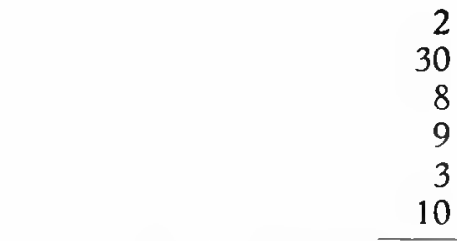

f. Other Business Electives

$\begin{array}{cr}\text { Total Technical } & 62 \\ \text { Total Required Points } & 130\end{array}$


( $A$ point is the equivalent of a semester hour and consists of one hour of classroom work a week for one term).

\section{SLOTWOORD.}

Uit al het voorgaande mag de conclusie getrokken worden, dat de gemiddelde studieduur voor wat betreft de theoretische scholing van de C.P.A. op vier jaren (dagstudie) mag gesteld worden, waarvan dan nog een belangrijk gedeelte wordt gewijd aan algemene ontwikkeling en voorbereidende vakstudie. De accountancy, de vakstudie in engere zin, legt beslag op circa $1 / 4$ van de beschikbare tijd. Anders uitgedrukt en alleen ten naastenbij correct: als men eerst de algemene ontwikkeling en de voorbereidende vakstudie zou geven en daarna uitsluitend accountancy, dan zou deze laatste studie slechts één universiteitsjaar in beslag nemen, na een driejarige voorstudie.

$\mathrm{Na}$ het behalen van de betreffende college degree (major accounting) moet men dan - als eerder gezegd - in de State of New York nog drie jaar praktijk hebben, waarna men tot het C.P.A. examen wordt toegelaten.

Gevoeglijk mag de conclusie getrokken worden, dat de accountantsstudie in Nederland zeer veel zwaarder is dan in de U.S.A. Het is moeilijk, zo niet onmogelijk om de verhouding tussen beide grootheden tot uitdrukking te brengen. Persoonlijk zou ik niet aarzelen te stellen, dat de studie in Nederland tweemaal zo zwaar is. Zo niet meer dan tweemaal zo zwaar.

Wie spreekt er onder deze omstandigheden in Nederland dan nog van verzwaren of van verlengen? Moet men aannemen, dat de Verenigde Staten van Noord Amerika wetenschappelijk tot de ,underdeveloped areas" behoren? 